\title{
An Analysis Unveiling the Habitation Coverage of Different States and Union Territories under the National Rural Drinking Water Program in India
}

\author{
N. Divya Lalitha' ${ }^{1}$, Sunayana Manipal ${ }^{2}$, Prabu.D ${ }^{3}$, Rajmohan ${ }^{2}$, Bharathwaj.V.V ${ }^{4}$ \\ ${ }^{1}$ Research Officer, National Oral Health Programme, Centre for Dental Education and Research, \\ All India Institute of Medical Sciences, New Delhi \\ ${ }^{2}$ Reader, ${ }^{3}$ Professor \& Head, ${ }^{4}$ Senior Lecturer, Department of Public Health Dentistry, \\ SRM Dental College, Chennai, Tamil Nadu \\ Corresponding Author: N. Divya Lalitha
}

\begin{abstract}
Background: National Rural Drinking Water Program (NRDWP) attempts to provide each and every individual a sufficient amount of safe water for drinking, cooking and other essential household needs on a maintainable premise, with a base water quality standard, which ought to be helpfully open consistently and in all circumstances.
\end{abstract}

Aim: The aim of this study was to analyze and unveil the habitations covered by the National Rural Drinking Water Program in different states and union territories of India.

Materials and method: Secondary data regarding the total households in each states/ union territory and the households covered by the National Rural Drinking Water Program, Households Having Safe Drinking Water supply in India as per Census 2011 and availability of safe drinking water in households and the source of drinking waters was extracted from the 2018 National Health Profile's annual publication by the Central Bureau of Health Intelligence (CBHI).

Results: In India,43\% of the households use tap water and $11 \%$ use well water. $46.6 \%$ of the households have water within the premises, $35.8 \%$ of the households have water near the premises and $17.6 \%$ have it far away. $81.08 \%$ are fully covered habitations under the program and only $3.34 \%$ of the habitations in India are quality affected habitations.

Conclusion: Although the targets have not been achieved, this program has attempted to provide safe drinking water to many people in different states and union territories in India.

Keywords: Rural areas, Habitations, Drinking water, India.

\section{INTRODUCTION}

Water is a basic substance of life. Without water, people can't live for more than some days. It assumes a crucial role in almost every capacity of the body, securing the insusceptible framework-the body's regular protections and helping evacuate waste matter.

Drinking water has for quite some time been of concern. In the start of the nineteenth century, the early research in drinking water concentrated on the contaminants nitrite, Bacillus coli, and toxic germs. Cleansing of drinking water by ozone, UV radiation, and chlorine for the expulsion of these contaminants was too detailed. ${ }^{[1]}$

During the 1970s, the event of organohalides in chlorinated drinking waters pulled in researchers' consideration. An advanced parallel of consideration on drinking water happens at the point when adequate water is accessible yet is so contaminated or saline that its uses are confined. Ever since the Industrial revolutions, ensuing contamination issues have happened and consistently expanded for a significant stretch of time. Since there 
has been a gigantic development in assembling and the utilization of manufactured synthetic substances from World War II, a significant number of these synthetic substances, for instance, bug sprays and herbicides, showed up and collected in the earth as overflow from farming area. ${ }^{[1]}$

An expected $80 \%$ of the total population faces an elevated level water security or water-related biodiversity chance. The issue of water security characterized as a worthy level of waterrelated dangers to people and environments, combined with the accessibility of water of adequate amount also, quality to help jobs, national security, human wellbeing, and biological system administrations is therefore getting impressive consideration. ${ }^{[2]}$

Rural Drinking Water Supply is a State subject. For improving the inclusion of satisfactory and safe drinking water to the provincial population, Ministry gives specialized and money related help through a Centrally Sponsored Scheme 'National Rural Drinking Water Program (NRDWP). The Program was started on 01.04.2009. The Program is being executed in all States and two Union Territories namely, Andaman and Nicobar Islands and Puducherry..$^{[3]}$

The Program has been rebuilt in November 2017 to make it progressively aggressive, result based and result arranged. The help is to accomplish the expect to furnish each country individual with sufficient safe water for drinking, cooking and other residential fundamental needs on a feasible premise which is to be promptly and helpfully available consistently and in all circumstances. This is in accordance with United Nation's Sustainable Development Goal (SDG) Target number 6, for example 'By 2030, accomplish widespread and evenhanded access to protected and reasonable drinking water for all'. [3]

Despite all these attempts, there is still water scarcity and lack of safe drinking water in many rural areas of India. People travel long distances in order to get water. Hence, this study attempts to analyze and unveil the habitations covered by the National Rural Drinking Water Program in different states and union territories of India.

\section{MATERIALS AND METHOD}

The aim of this study was to analyze and unveil the habitations covered by the National Rural Drinking Water Program in different states and union territories of India. It was also aimed to identify the states that have the least coverage out of all the states and union territories in India. Details about all the states and union territories in India were collected.

Secondary data regarding the total households in each states/ union territory and the households covered by the national rural drinking water program was extracted from the 2018 National Health Profile's annual publication by the Central Bureau of Health Intelligence (CBHI).

State/Union Territory wise Distribution of the Households Having Safe Drinking Water supply in India as per Census 2011 was extracted from the annual publication. Data regarding the availability of safe drinking water in households and the source of drinking waters used in every household was also recorded.

All the data regarding the availability and source of drinking water in each state and union territory was assessed. The households covered in every state/ union territory was analyzed and compared to evaluate the total number of households covered and efficiency of national rural drinking water program.

As the study was conducted in Tamil Nadu, the percentage of households getting safe drinking water was highlighted and compared with that of others to get a clear picture.

\section{RESULTS}

This study was conducted to assess, evaluate and compare the habitations covered under the National Rural Drinking 
N. Divya Lalitha et.al. An analysis unveiling the habitation coverage of different states and union territories under the national rural drinking water program in India

Water Program in different states and union tabulated and compared as follows: territories of India. The results were

Table 1: State and Union Territory Wise Habitations Coverage under National Rural Drinking Water Program in India

\begin{tabular}{|c|c|c|c|c|}
\hline $\begin{array}{l}\text { S. } \\
\text { No. }\end{array}$ & States & $\begin{array}{l}\text { Total number } \\
\text { of Habitations }\end{array}$ & $\begin{array}{c}\text { Total number of Habitations With } \\
\text { Population Coverage }>=0 \% \text { and }<100 \%\end{array}$ & $\begin{array}{c}\text { Total number of Habitations with } \\
100 \% \text { Population Coverage }\end{array}$ \\
\hline 1 & Andhra Pradesh & 48,363 & 15,041 & 32,898 \\
\hline 2 & Arunachal Pradesh & 7,582 & 4,641 & 2,910 \\
\hline 3 & Assam & 88,099 & 24,313 & 52,738 \\
\hline 4 & Bihar & $1,10,234$ & 38,680 & 67,314 \\
\hline 5 & Chhattisgarh & 74,685 & 3,045 & 70,459 \\
\hline 6 & Goa & 347 & 2 & 345 \\
\hline 7 & Gujarat & 36,066 & 4 & 36,062 \\
\hline 8 & Haryana & 7,948 & 224 & 7,596 \\
\hline 9 & Himachal Pradesh & 53,604 & 11,082 & 42,522 \\
\hline 10 & Jammu and Kashmir & 15,958 & 7,011 & 8,930 \\
\hline 11 & Jharkhand & $1,20,764$ & 898 & 11,6774 \\
\hline 12 & Karnataka & 60,248 & 39,106 & 19,877 \\
\hline 13 & Kerala & 21,551 & 16,401 & 4,751 \\
\hline 14 & Madhya Pradesh & $1,28,061$ & 117 & $12,7,754$ \\
\hline 15 & Maharashtra & 99,732 & 12,522 & 86,917 \\
\hline 16 & Manipur & 3,788 & 1,561 & 2,227 \\
\hline 17 & Meghalaya & 10,475 & 8,688 & 1,755 \\
\hline 18 & Mizoram & 738 & 272 & 466 \\
\hline 19 & Nagaland & 1,452 & 766 & 643 \\
\hline 20 & Odisha & $1,57,773$ & 16,276 & $13,8,420$ \\
\hline 21 & Punjab & 15,384 & 1,796 & 9,845 \\
\hline 22 & Rajasthan & $1,21,648$ & 46,971 & 54,034 \\
\hline 23 & Sikkim & 2,084 & 1,347 & 737 \\
\hline 24 & Tamil Nadu & 1,00204 & 7,474 & 92,532 \\
\hline 25 & Tripura & 8,723 & 1,614 & 4,526 \\
\hline 26 & Uttar Pradesh & $2,60,027$ & 2,346 & $25,6,302$ \\
\hline 27 & Uttarakhand & 39,360 & 17,406 & 21,938 \\
\hline 28 & West Bengal & $1,05,905$ & 36,497 & 50,098 \\
\hline 29 & Andhaman\& Nicobar Islands & 400 & 76 & 324 \\
\hline 30 & Telangana & 24,562 & 9,715 & 13,455 \\
\hline 31 & Puducherry & 266 & 113 & 153 \\
\hline & Total & $17,26,031$ & $3,26,005$ & $13,25,302$ \\
\hline
\end{tabular}

As on 01.04.2017, Source: National Health Profile $2018^{[4]}$

Table 1 shows the State and Union Territory wise Habitations Coverage under National Rural Drinking Water Program in India according to census 2011. While comparing the different states and union territories, it shows that the total Habitations covered in Goa is the least i.e. 347, the number of Habitations With Population Coverage more than or equal to $0 \%$ and less than $100 \%$ is only 2 , and the number of Habitations with $100 \%$ Population Coverage is 345. In the case of Tamilnadu, the total Habitations covered is 100204, the number of Habitations with Population Coverage more than or equal to $0 \%$ and less than $100 \%$ is 7474 , and the number of Habitations with 100\% Population Coverage is 92532 .

Table 2: State and Union Territory Wise Distribution of Households Having Tap and Well Water Supply in India According to census 2011

\begin{tabular}{|c|c|c|c|c|c|c|c|c|c|}
\hline \multirow{3}{*}{$\begin{array}{l}\text { S. } \\
\text { No }\end{array}$} & \multirow[t]{3}{*}{ State } & \multirow{3}{*}{$\begin{array}{l}\text { Number of } \\
\text { Households }\end{array}$} & \multicolumn{7}{|c|}{ Household distribution by availability of drinking water } \\
\hline & & & \multicolumn{3}{|c|}{ Tap water $(\%)$} & \multicolumn{3}{|c|}{ Well (\%) } & \multirow[t]{2}{*}{ Others (\%) } \\
\hline & & & Total & $\begin{array}{c}\text { Treated } \\
\text { source }\end{array}$ & $\begin{array}{l}\text { Untreated } \\
\text { source }\end{array}$ & Total & $\begin{array}{c}\text { Well } \\
\text { (Covered) }\end{array}$ & $\begin{array}{c}\text { Well } \\
\text { (Un-covered) }\end{array}$ & \\
\hline & India & 246740228 & 43.5 & 32.0 & 11.6 & 11.0 & 1.6 & 9.4 & 45.5 \\
\hline 1 & Andhra Pradesh & 21024534 & 69.9 & 49.0 & 20.9 & 6.4 & 0.5 & 5.9 & 23.7 \\
\hline 2 & Arunachal Pradesh & 261614 & 65.5 & 26.4 & 39.1 & 5.7 & 1.4 & 4.3 & 28.8 \\
\hline 3 & Assam & 6367295 & 10.5 & 9.2 & 1.3 & 18.9 & 1.7 & 17.2 & 70.6 \\
\hline 4 & Bihar & 18940629 & 4.4 & 3.1 & 1.3 & 4.3 & 0.7 & 3.7 & 91.3 \\
\hline 5 & Chhattisgarh & 5622850 & 20.7 & 12.3 & 8.4 & 11.4 & 0.8 & 10.6 & 67.9 \\
\hline 6 & Goa & 322813 & 85.4 & 82.0 & 3.4 & 11.1 & 4.0 & 7.1 & 3.5 \\
\hline 7 & Gujarat & 12181718 & 69.0 & 39.9 & 29.2 & 7.1 & 2.3 & 4.8 & 23.9 \\
\hline 8 & Haryana & 4717954 & 68.8 & 55.9 & 12.9 & 3.0 & 0.7 & 2.3 & 28.2 \\
\hline 9 & Himachal Pradesh & 1476581 & 89.5 & 83.9 & 5.6 & 2.9 & 1.5 & 1.3 & 7.6 \\
\hline
\end{tabular}


N. Divya Lalitha et.al. An analysis unveiling the habitation coverage of different states and union territories under the national rural drinking water program in India

\begin{tabular}{|c|c|c|c|c|c|c|c|c|c|}
\hline \multicolumn{10}{|c|}{ Table no. 2 continued... } \\
\hline 10 & Jammu and Kashmir & 2015088 & 63.9 & 34.7 & 29.2 & 6.5 & 1.9 & 4.7 & 29.6 \\
\hline 11 & Jharkhand & 6181607 & 12.9 & 10.0 & 2.9 & 36.5 & 1.9 & 34.6 & 50.6 \\
\hline 12 & Karnataka & 13179911 & 66.1 & 41.2 & 24.8 & 9.0 & 1.0 & 8.0 & 24.9 \\
\hline 13 & Kerala & 7716370 & 29.3 & 23.4 & 6.0 & 62.0 & 14.6 & 47.4 & 8.7 \\
\hline 14 & Madhya Pradesh & 14967597 & 23.4 & 16.4 & 6.9 & 20.0 & 1.1 & 18.9 & 56.6 \\
\hline 15 & Maharashtra & 23830580 & 67.9 & 56.3 & 11.6 & 14.4 & 2.2 & 12.2 & 17.7 \\
\hline 16 & Manipur & 554713 & 38.8 & 24.7 & 14.1 & 7.6 & 2.7 & 4.9 & 53.6 \\
\hline 17 & Meghalaya & 538299 & 39.3 & 27.8 & 11.5 & 25.4 & 6.9 & 18.4 & 35.3 \\
\hline 18 & Mizoram & 221077 & 58.7 & 39.4 & 19.3 & 4.7 & 2.0 & 2.7 & 36.6 \\
\hline 19 & Nagaland & 399965 & 47.2 & 6.1 & 41.1 & 25.7 & 6.6 & 19.1 & 27.1 \\
\hline 20 & Odisha & 9661085 & 13.8 & 10.0 & 3.9 & 19.5 & 2.2 & 17.3 & 66.7 \\
\hline 21 & Punjab & 5409699 & 51.0 & 41.1 & 9.9 & 0.4 & 0.2 & 0.2 & 48.6 \\
\hline 22 & Rajasthan & 12581303 & 40.6 & 32.0 & 8.5 & 10.8 & 1.2 & 9.6 & 48.6 \\
\hline 23 & Sikkim & 128131 & 85.3 & 29.2 & 56.1 & 0.6 & 0.5 & 0.2 & 14.1 \\
\hline 24 & Tamil Nadu & 18493003 & 79.8 & 55.8 & 23.9 & 5.1 & 1.2 & 3.8 & 15.1 \\
\hline 25 & Tripura & 842781 & 33.2 & 20.3 & 12.9 & 27.4 & 2.9 & 24.5 & 39.4 \\
\hline 26 & Uttar Pradesh & 32924266 & 27.3 & 20.2 & 7.1 & 4.0 & 0.6 & 3.4 & 68.7 \\
\hline 27 & Uttarakhand & 1997068 & 68.2 & 0.4 & 53.9 & 14.3 & 1.1 & 0.7 & 17.5 \\
\hline 28 & West Bengal & 20067299 & 25.4 & 21.0 & 4.4 & 6.0 & 0.7 & 5.4 & 68.6 \\
\hline 29 & $\begin{array}{l}\text { Andhaman\& } \\
\text { Nicobar Islands }\end{array}$ & 93376 & 85.0 & 68.8 & 16.2 & 7.3 & 0.7 & 6.6 & 7.7 \\
\hline 30 & Chandigarh & 235061 & 96.7 & 93.7 & 3.0 & 0.1 & 0.1 & 0.0 & 3.2 \\
\hline 31 & $\begin{array}{lll}\text { Dadra } & \& & \text { Nagar } \\
\text { Haveli } & & \\
\end{array}$ & 73063 & 46.5 & 26.0 & 20.5 & 7.2 & 1.4 & 5.7 & 46.3 \\
\hline 32 & Daman \& Diu & 60381 & 75.2 & 54.6 & 20.6 & 0.7 & 0.5 & 0.2 & 24.1 \\
\hline 33 & NCT of Delhi & 3340538 & 81.3 & 75.2 & 6.1 & 0.1 & 0.1 & 0.0 & 18.6 \\
\hline 34 & Lakshadweep & 10703 & 20.3 & 9.1 & 11.1 & 71.7 & 6.9 & 64.9 & 8.6 \\
\hline 35 & Puducherry & 301276 & 95.3 & 90.8 & 4.5 & 1.9 & 0.1 & 1.8 & 2.8 \\
\hline
\end{tabular}

Table 3: Distribution Based On Availability of Drinking Water Source among Different States and Union Territories In India

\begin{tabular}{|c|c|c|c|c|}
\hline \multirow{2}{*}{$\begin{array}{c}\text { S. } \\
\text { No. }\end{array}$} & \multirow[b]{2}{*}{ State } & \multicolumn{3}{|c|}{ Source of Drinking Water } \\
\hline & & $\begin{array}{c}\text { Within the } \\
\text { Premises (\%) }\end{array}$ & $\begin{array}{c}\text { Near the } \\
\text { Premises (\%) }\end{array}$ & Away (\%) \\
\hline & India & 46.6 & 35.8 & 17.6 \\
\hline 1 & Andhra Pradesh & 43.2 & 37.3 & 19.5 \\
\hline 2 & Arunachal Pradesh & 41.1 & 37.4 & 21.6 \\
\hline 3 & Assam & 54.8 & 26.7 & 18.5 \\
\hline 4 & Bihar & 50.1 & 37.9 & 12.0 \\
\hline 5 & Chhattisgarh & 19.0 & 54.5 & 26.5 \\
\hline 6 & Goa & 79.7 & 15.5 & 4.8 \\
\hline 7 & Gujarat & 64.0 & 23.5 & 12.4 \\
\hline 8 & Haryana & 66.5 & 21.4 & 12.1 \\
\hline 9 & Himachal Pradesh & 55.5 & 35.0 & 9.5 \\
\hline 10 & Jammu and Kashmir & 48.2 & 28.7 & 23.1 \\
\hline 11 & Jharkhand & 23.2 & 44.9 & 31.9 \\
\hline 12 & Karnataka & 44.5 & 37.3 & 18.2 \\
\hline 13 & Kerala & 77.7 & 14.1 & 8.2 \\
\hline 14 & Madhya Pradesh & 23.9 & 45.6 & 30.5 \\
\hline 15 & Maharashtra & 59.4 & 27.6 & 13.1 \\
\hline 16 & Manipur & 15.5 & 47.3 & 37.2 \\
\hline 17 & Meghalaya & 24.1 & 43.2 & 32.7 \\
\hline 18 & Mizoram & 31.2 & 46.7 & 22.2 \\
\hline 19 & Nagaland & 29.3 & 42.4 & 28.3 \\
\hline 20 & Odisha & 22.4 & 42.2 & 35.4 \\
\hline 21 & Punjab & 85.9 & 10.0 & 4.1 \\
\hline 22 & Rajasthan & 35.0 & 39.0 & 25.9 \\
\hline 23 & Sikkim & 52.6 & 29.7 & 17.7 \\
\hline 24 & Tamil Nadu & 34.9 & 58.1 & 7.0 \\
\hline 25 & Tripura & 37.1 & 30.5 & 32.4 \\
\hline 26 & Uttar Pradesh & 51.9 & 36.0 & 12.1 \\
\hline 27 & Uttarakhand & 58.3 & 26.6 & 15.2 \\
\hline 28 & West Bengal & 38.6 & 34.7 & 26.6 \\
\hline 29 & Andaman \& Nicobar Islands & 60.6 & 27.0 & 12.4 \\
\hline 30 & Chandigarh & 86.1 & 11.7 & 2.2 \\
\hline 31 & Dadra \& Nagar Haveli & 52.6 & 36.4 & 11.0 \\
\hline 32 & Daman \& Diu & 76.4 & 22.1 & 1.5 \\
\hline 33 & Delhi & 78.4 & 15.4 & 6.2 \\
\hline 34 & Lakshadweep & 83.7 & 14.3 & 2.0 \\
\hline 35 & Puducherry & 77.4 & 21.5 & 1.1 \\
\hline
\end{tabular}


Table 2 shows the State and Union Territory wise Distribution of Households having Tap and Well Water Supply in India according to Census 2011. While comparing the different states and union territories, it shows that in Sikkim, 56.1\% of them use tap water from untreated sources. In Tamilnadu, 23.9\% of them use tap water from untreated sources and about $3.8 \%$ of the households use water from uncovered wells.

Table 3 shows the Distribution Based on Availability of Drinking Water Source among Different States and Union Territories in India. It shows that in India,46.6\% of the households have water within the premises, $35.8 \%$ of the households have water near the premises and $17.6 \%$ have it far away. In Tamilnadu, $34.9 \%$ of the households have water within the premises, majorly $58.1 \%$ of the households have water near the premises itself and only $7 \%$ have it far away.

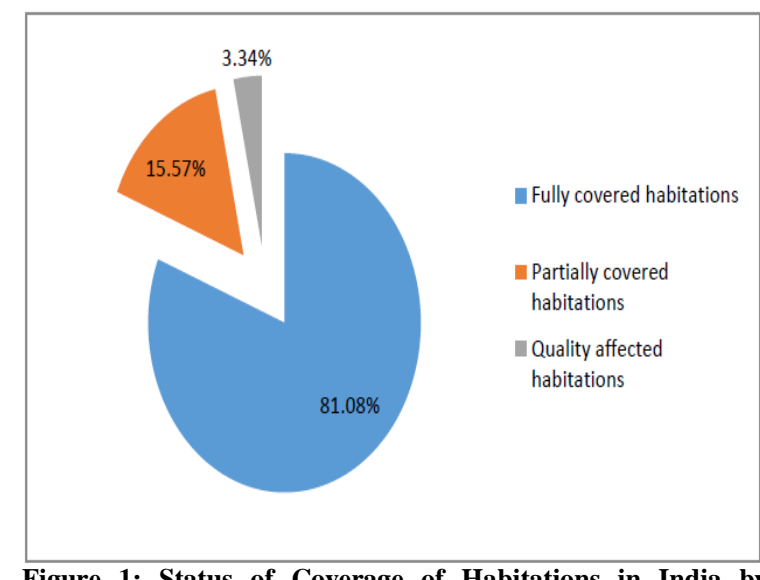

National Rural Drinking Water Program

Figure 1 shows the Status of Coverage of Habitations in India by National Rural Drinking Water Program. It shows that about $81.08 \%$ are fully covered habitations under the program and only $3.34 \%$ of the habitations in India are quality affected habitations.

\section{DISCUSSION}

Safe healthy water and fundamental sanitation offices are human rights. With the fast increment in urban population, arrangement of open, reasonable and adequate safe drinking water and sanitation office in Indian households is a test. ${ }^{[5]}$

Nonavailability of adequate amount of clean water in family units necessitates the need for use of water from some polluted and other sources. This training contrarily influences the wellbeing of individuals, which is reflected by the expanded weight of waterborne ailments, particularly among under-five old children. ${ }^{[6]}$

National Rural Drinking Water Program (NRDWP) attempts to provide safe drinking water in India for all the rural households. It attempts to provide each and every individual a sufficient amount of safe water for drinking, cooking and other essential household needs on a maintainable premise, with a base water quality standard, which ought to be helpfully open consistently and in all circumstances. Accomplishing this point and target is a consistent procedure. ${ }^{[6]}$

The comparison between different states and union territories of India under NRDWP, shows that the total Habitations covered in Goa is the least i.e. 347, the number of Habitations with Population Coverage more than or equal to $0 \%$ and less than $100 \%$ is only 2 , and the number of Habitations with 100\% Population Coverage is 345. In the case of Tamilnadu, the total Habitations covered is 100204, the number of Habitations with Population Coverage more than or equal to $0 \%$ and less than $100 \%$ is 7474 , and the number of Habitations with 100\% Population Coverage is 92532 by National Rural Drinking Water Program. Lack of proper implementation of the program, distribution of resources, community involvement could be a reason behind this scenario.

While comparing the different states and union territories in table 2, it shows that in Sikkim, $56.1 \%$ of them use tap water from untreated sources. In Tamilnadu, $23.9 \%$ of them use tap water from untreated sources and about $3.8 \%$ of the households use water from uncovered wells. In studies conducted in Myanmar ${ }^{[7]}$ and Vietnam [8] 
there were higher proportion of household who use water from piped supply. In the present study, while this was assessed, about $43.5 \%$ of the households use piped water. Out of this only about $32 \%$ of the household use tap water from treated sources. Poor execution of work, poor contract managements, incomplete or abandoned works, non-functional sustainable structures, unproductive investments on equipments can be regarded as a reason to this scenario in India.

In the present study, according to table 3 , about $17.6 \%$ of households have water availability far away from their house premises. Household individuals who don't need to head out to gather water possess more energy for child care, keeping up of individual cleanliness and can take an interest in beneficial financial exercises. ${ }^{[9,10]}$ In a review of 45 developing nations in Eastern and Southern Africa, it was accounted for that in $12 \%$ of households where youngsters gather water, young ladies were included twice as regularly when contrasted with young men. They frequently need to walk long separations to bring water, promptly in the first part of the day, prompting poor school participation, and dropout. $^{[11,12]}$

The present study results in Figure 1 shows that about $81.08 \%$ are fully covered habitations under the program and only $3.34 \%$ of the habitations in India are quality affected habitations. This shows that although there is an improved access to water in India other than any nation, there are still some people with no access to safe drinking water.

Although the targets have not been reached, many of the rural areas in India have been benefitted by the National Rural Drinking Water Program. Many people have access to safe drinking water nowadays, yet many people are to be educated about safe drinking water and its health effects. Many such programs are yet to be implemented to provide safe drinking water to all the people in the community.

\section{CONCLUSION}

This study evaluated the habitation coverage under National Rural Drinking Water Program among different states and union territories in India. As discussed earlier, even though the targets have not been achieved, this program has attempted to provide safe drinking water to many people in different states and union territories in India. Many such programs to provide adequate safe drinking water to all the people must be implements by organized community efforts.

Conflict of Interest: Authors declare no conflict of interest

\section{Acknowledgement: None}

\section{Source of Funding: None}

\section{REFERENCES}

1. Fu HZ, Wang MH, Ho YS. Mapping of drinking water research: A bibliometric analysis of research output during 19922011. Science of the Total Environment, 443,757-65, (2013)

2. Bakker K. Water security: research challenges and opportunities. Science, 337(6097), 914-5.(2012)

3. National Rural Drinking Water Programme. [Internet]. Nrdwp.gov.in. 2019 [cited 2021 May 26]. Available from: https://nrdwp.gov.in.

4. Cdn.downtoearth.org.in. (2018). [online] Available at: https://cdn.downtoearth.org.in/pdf/NHP2018.pdf [Accessed 3 May. 2021].

5. Bhar D, Bhattacherjee S, Mukherjee A, Sarkar TK, Dasgupta S. Utilization of safe drinking water and sanitary facilities in slum households of Siliguri, West Bengal. Indian journal of public health. 61(4), 248-253, (2017)

6. National Rural Drinking Water Programme [Internet]. Pib.gov.in. 2019 [cited 2021 May 26]. Available from: https://pib.gov.in/newsite/mbErel.aspx?relid $=100016$

7. Brown J, Hien VT, McMahan L, Jenkins MW, Thie L, Liang K, et al. Relative benefits of on-plot water supply over other 'improved' sources in rural Vietnam. Trop Med Int Health, 18, 65-74.(2013) 
N. Divya Lalitha et.al. An analysis unveiling the habitation coverage of different states and union territories under the national rural drinking water program in India

8. Tumwine JK, Katui-Katua M, Munguti KK. Drawers of Water. II: 30 Years of Change in Domestic use and Environmental Health in East Africa. London: International Institute for Environment and Development; 2002.

9. The Right to Water. Geneva: World Health Organization; 2003. Available from: http://www.who.int/water_sanitation_health /en/righttowater.pdf.

10. [Last accessed on 2020 May 26].

11. Mehta L. Challenges and Achievements in the Implementation of the Millennium Development Goals for Women and Girls. United Nations Commission on the Status of Women Fifty-Seventh Session. Interactive Expert Panel. New York; 4-15 March, 2013. Available from: http://www.un.org/womenwatch/daw/csw/cs w57/panels/otherpanels-paper-lylamehta.pdf. [Last accessed on 2021 May 26].
12. Gender and Water, Sanitation and Hygiene (WASH). Available from: http://www.unicef.org/esaro/7310_Gender_ and_WASH.html. [Last accessed on 2021 may 26].

13. Tanzanian Women Bring Safe Drinking Water to their Communities. Available from: http://www.unwomen.org/en/news/sto ries/2013/3/

14. Tanzanian-water-kiosks. [Last accessed on 2021 May 26].

How to cite this article: N. Divya Lalitha, Sunayana Manipal, Prabu.D et.al. An analysis unveiling the habitation coverage of different states and union territories under the national rural drinking water program in India. International Journal of Research and Review. 2021; 8(12): 182-188. DOI: https://doi.org/ 10.52403/ijrr.20211224 